\title{
Neuropsychomotor development characteristics of the infants who born from women who used drugs during pregnancy
}

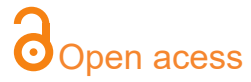

${ }^{1}$ Fisioterapeuta, Programa de Residência em Área Profissional da Saúde, Universidade Federal de Uberlândia, Uberlândia, Minas Gerais, Brasil.

${ }^{2}$ Fisioterapeuta, Hospital de Clínicas, Universidade Federal de Uberlândia, Uberlândia, Minas Gerais, Brasil. ${ }^{3}$ Estatístico, Centro de Ciências Exatas e Tecnologia, Faculdade de Matemática. Universidade Federal de Uberlândia. Uberlândia, Minas Gerais, MG, Brasil.

${ }^{4}$ Enfermeira, Pesquisadora em Saúde Coletiva, Mestranda do Programa de Pós-Graduação em Ciências da Saúde, Universidade Federal de Uberlândia, Uberlândia, Minas Gerais, Brasil.

${ }^{5}$ Fisioterapeuta, Doutora, Docente do Curso de Fisioterapia, Faculdade de Educação Física e Fisioterapia, Universidade Federal de Uberlândia, Uberlândia, Minas Gerais, Brasil.

Corresponding author: vivian.azevedo@ufu.br

Manuscript received: July 2017 Manuscript accepted: December 2017 Version of record online: March 2018
Roberta Elian de Lima1 ${ }^{1}$, Andrezza Aparecida Aleixo², Lúcio Borges de Araújo ${ }^{3}$, Camila Piqui Nascimento ${ }^{4}$, Vivian Mara Gonçalves de Oliveira Azevedo ${ }^{5}$

\begin{abstract}
Introduction: The use of street drugs during pregnancy, due to their deleterious effects on the health of the infant, may have clinical implications for neuropsychomotor development.

Objective: The aim of this study was to analyse the characteristics of the neuropsychomotor development of infants born from women who used street drugs during pregnancy.
\end{abstract}

Methods: A cross-sectional retrospective study was carried out. A total of 51 medical records of infants weighing less than 1.500 grams, who were born in the Hospital de Clínicas da Universidade Federal de Uberlândia (HC/UFU), Minas Gerais, Brazil, from January 2014 to December 2015 were analysed. Using the Development Screening test Denver II at 6 or 9 months of corrected age performed the neuropsychomotor development evaluation. Statistical analysis included quantitative variables that were described by means of average, medians and standard deviation. Groups were compared by the test or Mann-Whitney test. The associations of the qualitative variables were evaluated by means of the likelihood ratio test.

Results: Of the 51 records analysed, $39.2 \%$ belong to the group of children of mothers who used street drugs and $60.8 \%$ belong to the group of children of nonuser mothers. The neuropsychomotor development was predominantly abnormal and with a significant difference in the general performance classification $(p<0.001)$ and, specifically, in the coarse motor area $(p=0.003)$ in the group of infants born to mothers who used street drugs.

Conclusion: Infants of mothers who used street drugs had a greater delay in neuropsychomotor development.

Keywords: street drugs, infants, child development, pregnant women. 


\section{INTRODUCTION}

Exposure to substances such as tobacco, alcohol or street drugs can compromise the development of the individual at all stages of life, since the intrauterine period ${ }^{1}$. The use of street drugs by women during the fertile period has been growing worldwide and has become a public health issue $^{2}$.

In the United States, the prevalence of use of street drugs during pregnancy in women aged 1544 years was $10.8 \%$ for alcohol, $3 \%$ for tobacco and $4.4 \%$ for street drugs, with a more frequent use among younger women ${ }^{3}$. In Brazil, there are few studies on the subject. However, an analysis carried out in the city of São Luis, MA, with 1447 pregnant women, concluded that the use of psychoactive substances during pregnancy was $22.3 \%$ with regard to alcohol use, $4.2 \%$ tobacco use and $1.4 \%$ of some type of illicit drug ${ }^{4}$.

The use of street drugs during pregnancy can be devastating, since in some cases it results

\section{METHODS}

This is a cross-sectional study with medical records of infants from the Hospital de Clínicas da Universidade Federal de Uberlândia (HC/UFU), Minas Gerais, Brazil, from January 1st, 2014 to December 31 st, 2015.

We included 51 medical records of preterm new-borns weighing less than 1.500 grams at birth and at 6 and 9 months of corrected gestational age. The infants were divided into two groups: Group 1 - (20 infants) children of street drugs users; and Group 2 - (31 infants) children of non-users.

The maternal variables were gestational age, prenatal, maternal age, schooling, use of street and/ or licit drugs, gestational diabetes mellitus, chronic hypertension, peri-natal haemorrhage, neonatal steroid use, chorioamnionitis and type of delivery.

Neonatal variables that were analysed: gender, length, weight and cephalic perimeter at birth, apgar score at 5 minutes of life, neonatal infection, congenital infection, surfactant use, oxygen therapy time, time of invasive mechanical ventilation, bronchopulmonary dysplasia, periventricular haemorrhage, leukomalacia, ductus arteriosus persistence, enterocolitis, SNAP-PE scale and length of hospital stay in the Neonatal Intensive Care Unit (NICU).

Neuropsychomotor development of infants was evaluated by the Denver II Development Screening Test and compared the groups: Group 1 - children exposed to street drugs during pregnancy and Group 2 - children not exposed to street drugs during pregnancy. The test evaluates children's development from 0 to 6 years and consists of 125 items, which are divided into four areas: socialpersonal, fine-adaptive motor, language and large or gross motor. Each of the evaluated items is classified in: delay, caution or attention and passes. The 90th in irreversible consequences to the mother-fetus binomial $^{5}$. This happens because the drug can overcome the placental and blood-brain barrier, without previous metabolism, acting mainly on the central nervous system of the fetus. Due to their deleterious effects on infant health, these drugs may still have clinical implications for neuropsychomotor development, as well as the social and economic impact on health ${ }^{6}$.

Thus, the use of maternal and neonatal screening techniques on children exposed to intrauterine street drugs is extremely important, with the aim of promoting, preventing and intervening early, avoiding postnatal complications of the child's development ${ }^{7}$.

Therefore, the objective is to analyse the characteristics of the neuropsychomotor development of infants born from mothers who used street drugs during pregnancy.

percentile is the cut-off point used in the Denver II test to define the delay. When the child fails an item or test, and is totally in the left side of the age line, i.e. in addition to the p90; caution, or attention when the child fails a test that was intercepted by the age line between p75 and p90 and passes when the child successfully performs the test ${ }^{8-10}$.

The performance of each infant was classified according to the number of failures (delay and caution) and classified as: abnormal - when the infant had two or more delays independent of the area or sector; questionable - when the evaluated infant presented only one delay or two or more cautions; normal - when the infant presented no delay and at most a caution ${ }^{8,9}$.

The statistical analysis included quantitative variables, which were described, within each group, in averages, medians and standard deviations. The Shapiro-Wilk normality test was applied, and the Student's t-test was applied to the variables that presented normal distribution in the two groups, otherwise the Mann-Whitney test was applied. The associations of the qualitative variables were evaluated using the likelihood ratio test ( $G$ test). Univariate logistic regression was used to evaluate the risk factors for the occurrence of delayed neuropsychomotor development. For the elaboration of the database and statistical analysis the SPSS program, version 20.0 was used and the level of significance was adopted of $5 \%$.

The study was approved by the Research Ethics Committee of the Federal University of Uberlândia (Protocol 1628014) and obeyed the norms for conducting research with humans, according to Resolution $466 / 12$ of the National Health Council. Numbers identified patients in order to preserve your identity. 


\section{RESULTS}

We analysed 51 medical records, 20 (39.2\%) belonging to Group 1 (children of street drugs user mothers) and $31(60.8 \%)$ to Group 2 (children of nonuser mothers).

Maternal characteristics are presented in Table 1. The consumption of licit drugs (alcohol and tobacco) was $27.5 \%$ and $11.8 \%$ of street drugs (marijuana, crack, cocaine) concomitant with licit drugs. With regard to schooling, $72.5 \%$ studied from 8 to 11 years and, in relation to prenatal care, $92.2 \%$ had medical appointments.

Table 1: Maternal characteristics of women who used drug during pregnancy

\begin{tabular}{|c|c|c|c|c|c|c|c|}
\hline $\begin{array}{l}\text { Variable } \\
\text { Drug types }\end{array}$ & \multicolumn{2}{|c|}{ Total } & \multicolumn{2}{|c|}{$\begin{array}{c}\text { Group } \\
n=20\end{array}$} & \multicolumn{2}{|c|}{$\begin{array}{c}\text { Group } 2 \\
n=31\end{array}$} & $p$ value \\
\hline Licit drugs & 14 & 27,5 & 14 & 70,0 & 0 & 0,0 & \multirow{4}{*}{$<0,001$} \\
\hline Street drugs & 0 & 0,0 & 0 & 0,0 & 0 & 0,0 & \\
\hline Licit and street drugs & 6 & 11,8 & 6 & 30,0 & 0 & 0,0 & \\
\hline Non user & 31 & 60,8 & 0 & 0,0 & 31 & 100,0 & \\
\hline \multicolumn{8}{|l|}{ Years of study } \\
\hline $1-3$ years & 1 & 2,0 & 1 & 5,0 & 0 & 0,0 & \multirow{4}{*}{0,014} \\
\hline $4-7$ years & 5 & 9,8 & 2 & 10,0 & 3 & 9,7 & \\
\hline $8-11$ years & 37 & 72,5 & 17 & 85,0 & 20 & 64,5 & \\
\hline 12 years or more & 8 & 15,7 & 0 & 0,0 & 8 & 25,8 & \\
\hline \multicolumn{8}{|l|}{ Prenatal care } \\
\hline Yes & 47 & 92,2 & 16 & 80,0 & 31 & 100,0 & \multirow{2}{*}{0,039} \\
\hline No & 4 & 7,8 & 4 & 20,0 & 0 & 0,0 & \\
\hline \multicolumn{8}{|c|}{ Chronic arterial hypertension } \\
\hline Yes & 15 & 29,4 & 2 & 10,0 & 13 & 41,9 & \multirow{2}{*}{0.033} \\
\hline No & 36 & 70,6 & 18 & 90,0 & 18 & 58,1 & \\
\hline \multicolumn{8}{|l|}{ Gestational diabetes } \\
\hline Yes & 1 & 2,0 & 0 & 0,0 & 1 & 3,2 & \multirow{2}{*}{0.315} \\
\hline No & 50 & 98,0 & 20 & 100,0 & 30 & 96,8 & \\
\hline \multicolumn{8}{|l|}{ Chorioamnionitis } \\
\hline Yes & 10 & 19,6 & 5 & 25,0 & 5 & 16,1 & \multirow{2}{*}{0.440} \\
\hline No & 41 & 80,4 & 15 & 75,0 & 26 & 83,9 & \\
\hline \multicolumn{8}{|l|}{ Antenatal Steroid } \\
\hline Yes & 32 & 62,7 & 10 & 50,0 & 22 & 71,0 & \multirow{2}{*}{0,131} \\
\hline No & 19 & 37,3 & 10 & 50,0 & 9 & 29,0 & \\
\hline \multicolumn{8}{|l|}{ Periparturient haemorrhage } \\
\hline Yes & 4 & 7,8 & 2 & 10,0 & 2 & 6,5 & \multirow{2}{*}{0,649} \\
\hline No & 47 & 92,2 & 18 & 90,0 & 29 & 6,5 & \\
\hline \multicolumn{8}{|l|}{ Birth type } \\
\hline Caesarean & 34 & 66,7 & 8 & 40,0 & 26 & 83,9 & \multirow{2}{*}{0,001} \\
\hline Vaginal & 17 & 33,3 & 12 & 60,0 & 5 & 16,1 & \\
\hline
\end{tabular}

When the groups were compared, it was observed that the neonatal population exposed to drugs in the gestational period (Table 2) presented significant data for neonatal infection $(\mathrm{p}<0.001)$ and bronchopulmonary dysplasia $(p=0.001)$. Children exposed to intrauterine street drugs remained for a longer period hospitalized in the NICU when compared to children of non-users ( $\mathrm{p}=$ 0.027) (Table 3).

In the assessment of the neuropsychomotor development of infants (Table 4), a statistically significant difference was observed in the overall performance classification $(\mathrm{p}<0.001)$, with the gross motor area $(\mathrm{p}$ $=0.003$ ) being the most affected and with the highest number of delays in the infants exposed to drugs of abuse during the gestational period.

Univariate logistic regression made it possible to compare the use of street drugs with other neonatal variables as risk factors that may increase the chances of delayed neuropsychomotor development (Table 5). It was possible to observe that the time of oxygen use $(\mathrm{OR}=$ $1.06,95 \%$ CI 1.02-1.10), length of hospital stay (OR $=$ $1.05,95 \%$ CI 1.02-1.08) and, mainly the patent ductus arteriosus $(\mathrm{OR}=7.00,95 \%$ CI $1.86-26.36)$ were factors that also increased the risk for delayed neuropsychomotor development. 
Table 2: Characteristics of new-born children of street drug users (G1) and children of non-users (G2), Uberlandia - MG, Brazil, 2018

\begin{tabular}{|c|c|c|c|c|c|c|c|}
\hline \multirow{2}{*}{$\begin{array}{l}\text { Variable } \\
\text { Sex }\end{array}$} & \multicolumn{2}{|l|}{ total } & \multicolumn{2}{|c|}{$\begin{array}{c}\text { Group } 1 \\
n=20\end{array}$} & \multicolumn{2}{|c|}{$\begin{array}{c}\text { Group } 2 \\
\mathrm{n}=31\end{array}$} & \multirow[t]{2}{*}{$p$ value } \\
\hline & & & & & & & \\
\hline Male & 33 & 64,7 & 12 & 60,0 & 21 & 67,7 & \multirow{2}{*}{0,573} \\
\hline Female & 18 & 35,3 & 8 & 40,0 & 10 & 32,3 & \\
\hline \multicolumn{8}{|l|}{ Use of surfactant } \\
\hline Yes & 28 & 54,9 & 12 & 60,0 & 15 & 48,4 & \multirow{2}{*}{0,556} \\
\hline No & 23 & 45,1 & 8 & 40,0 & 16 & 51,6 & \\
\hline \multicolumn{8}{|c|}{ Bronchopulmonary dysplasia } \\
\hline Yes & 22 & 43,1 & 14 & 70,0 & 8 & 25,8 & \multirow{2}{*}{0,001} \\
\hline No & 29 & 56,9 & 6 & 30,0 & 23 & 74,2 & \\
\hline \multicolumn{8}{|c|}{ Periventricular Leukomalacia } \\
\hline Yes & 1 & 2,0 & 0 & 0,0 & 1,0 & 3,2 & \multirow{2}{*}{0,315} \\
\hline No & 50 & 98,0 & 20 & 100,0 & 30,0 & 96,8 & \\
\hline \multicolumn{8}{|c|}{ Persistence of the Arterial Canal } \\
\hline Yes & 26 & 51,0 & 11 & 55,0 & 15 & 48,4 & \multirow{2}{*}{0,644} \\
\hline No & 25 & 49,0 & 9 & 45,0 & 16 & 51,6 & \\
\hline \multicolumn{8}{|l|}{ Necrosing enterocolitis } \\
\hline Yes & 4 & 7,8 & 2 & 10,0 & 2 & 6,5 & \multirow{2}{*}{0,649} \\
\hline No & 47 & 92,0 & 18 & 90,0 & 29 & 93,5 & \\
\hline \multicolumn{8}{|l|}{ Neonatal infection } \\
\hline Yes & 24 & 52,9 & 16 & 80,0 & 8 & 25,8 & \multirow{2}{*}{$<0,001$} \\
\hline No & 27 & 47,1 & 4 & 20,0 & 23 & 74,2 & \\
\hline \multicolumn{8}{|l|}{ Congenital infection } \\
\hline Yes & 4 & 7,8 & 3 & 15,0 & 1 & 3,2 & \multirow{2}{*}{0,129} \\
\hline No & 47 & 92,2 & 17 & 85,0 & 30 & 96,8 & \\
\hline \multicolumn{8}{|c|}{ Degree of Perinterventricular Haemorrhage } \\
\hline No Haemorrhage & 38 & 74,5 & 12 & 60,0 & 26 & 83,9 & \multirow{5}{*}{0,246} \\
\hline Degree 1 & 5 & 9,8 & 3 & 15,0 & 2 & 6,5 & \\
\hline Degree 2 & 4 & 7,8 & 3 & 15,0 & 1 & 3,2 & \\
\hline Degree 3 & 4 & 7,8 & 2 & 10,0 & 2 & 6,5 & \\
\hline Degree 4 & 0 & 0,0 & 0 & 0,0 & 0 & 0,0 & \\
\hline
\end{tabular}

Table 3: Comparison of maternal and neonatal characteristics between the groups (Group 1 - users of street drugs and Group 2 - non-users), Uberlandia - MG, Brazil, 2018

\begin{tabular}{lccccc}
\hline Variable & \multicolumn{2}{c}{$\begin{array}{c}\text { Group 1 } \\
\text { n=20 }\end{array}$} & \multicolumn{2}{c}{$\begin{array}{c}\text { Group 2 } \\
\mathbf{n = 3 1}\end{array}$} & p value \\
\hline & Average & SD & Average & SD & \\
Gestational Age (weeks) & 29,6 & 2,7 & 28,8 & 2,4 & 0,121 \\
Maternal Age (years) & 25,0 & 6,6 & 26,0 & 6,2 & 0,377 \\
Birth Weight (grams) & 1059,4 & 257,3 & 1089,2 & 254,5 & 0,941 \\
Length of Birth (centimetre) & 36,1 & 3,04 & 36,2 & 2,37 & 0,801 \\
Cephalic perimeter to birth & 24,7 & 2,1 & 25,4 & 2,2 & 0,378 \\
(centimetre) & & & & & \\
5th Minute Apgar Score & 8,0 & 1,1 & 7,8 & 1,2 & 0,835 \\
Oxygen therapy (days) & 39,6 & 31,8 & 22,9 & 33,8 & 0,088 \\
Mechanical ventilation & 11,4 & 16,0 & 4,2 & 7,9 & 0,075 \\
(days) & & & & & \\
Length of stay (days) & 80,3 & 28,4 & 59,9 & 32,7 & 0,027 \\
SNAP-PE & 29,7 & 21,9 & 32,4 & 17,4 & 0,621 \\
\hline
\end{tabular}


Table 4: Comparison of neuropsychomotor development between the groups according to the Denver II test, Uberlandia - MG, Brazil, 2018

\begin{tabular}{|c|c|c|c|c|}
\hline Denver II & $\begin{array}{c}\text { Group } 1 \\
n=20\end{array}$ & $\begin{array}{c}\text { Group } 2 \\
n=31\end{array}$ & $\begin{array}{l}\text { Total } \\
n=51\end{array}$ & $p$ value \\
\hline \multicolumn{5}{|l|}{ Personal - Social } \\
\hline Normal & 14 & 25 & 39 & \multirow{5}{*}{0,334} \\
\hline 1 delay & 3 & 3 & 6 & \\
\hline 2 delays & 3 & 1 & 4 & \\
\hline 3 delays & 0 & 1 & 1 & \\
\hline 1 caution & 0 & 1 & 1 & \\
\hline \multicolumn{5}{|l|}{ Language } \\
\hline Normal & 12 & 25 & 37 & \multirow{5}{*}{0,122} \\
\hline 1 delay & 7 & 4 & 11 & \\
\hline 2 delays & 0 & 1 & 1 & \\
\hline 1 caution & 1 & 0 & 1 & \\
\hline 2 cautions & 0 & 1 & 1 & \\
\hline \multicolumn{5}{|c|}{ Adaptive Fine Motor } \\
\hline Normal & 12 & 26 & 38 & \multirow{6}{*}{0,118} \\
\hline 1 delay & 2 & 1 & 3 & \\
\hline 2 delays & 3 & 1 & 4 & \\
\hline 3 delays & 2 & 0 & 2 & \\
\hline 1 caution & 1 & 2 & 3 & \\
\hline 2 cautions & 0 & 1 & 1 & \\
\hline \multicolumn{5}{|l|}{ Gross Motor } \\
\hline Normal & 5 & 17 & 22 & \multirow{6}{*}{0,003} \\
\hline 1 delay & 8 & 6 & 14 & \\
\hline 2 delays & 4 & 2 & 6 & \\
\hline 3 delays & 3 & 0 & 3 & \\
\hline 1 caution & 0 & 2 & 2 & \\
\hline 2 cautions & 0 & 4 & 4 & \\
\hline \multicolumn{5}{|c|}{ Performance Rating } \\
\hline Abnormal & 14 & 4 & 18 & \multirow{3}{*}{$<0,001$} \\
\hline Questionable & 4 & 11 & 15 & \\
\hline Normal & 2 & 16 & 18 & \\
\hline
\end{tabular}

Table 5: Odds ratio values and respective 95\% confidence intervals for risk factors to which new-borns were exposed and that could influence neuropsychomotor development, Uberlandia - MG, Brazil, 2018

\begin{tabular}{lccc}
\hline Variable & $\mathbf{O R}^{*}$ & $\mathbf{C l}^{*} \mathbf{9 5 \%}$ & $\mathbf{p}$ value \\
\hline Oxygen Time & 1,0 & $1,02-1,10$ & 0,005 \\
Mechanical Ventilation Time & 1,2 & $0,98-1,58$ & 0,073 \\
Length of stay & 1,0 & $1,02-1,08$ & 0,004 \\
Canal Arterial Patent & 7,0 & $1,86-26,36$ & 0,004 \\
\hline
\end{tabular}

${ }^{*}$ OR, Odds Ratio; $\mathrm{Cl}$, Confidence Interval.

\section{DISCUSSION}

In this study, infants whose mothers used street drugs during pregnancy had a greater delay in neuropsychomotor development when compared to infants born to non-users.

In the findings of Miller-Loncar et al. ${ }^{11}$, when evaluating the motor development pattern during the first 18 months of children's life with utero exposure to street drugs, they observed that infants with cocaine exposure had low motor skills with 1 month old, but have had a significant increase in these abilities over time. In addition, the authors reported that both the highest and lowest levels of tobacco use were related to the poorest motor performance on average. 
Belcher et al..$^{12}$ also observed a higher prevalence in the delay of the gross motor development of infants exposed to street drugs in intrauterine life when compared to the unexposed infants. The acquisition of motor milestones, such as rolling and walking, were delayed and presented abnormal tonus patterns.

In the United Kingdom, in a longitudinal study evaluating infants, children of women using recreational drugs (ecstasy) during pregnancy, from birth to 4, 12, 18 and 24 months of age, it was shown that exposure (greater use of tablets per week) resulted in worse motor development, but without affecting mental development. These infants with more intense exposure were twice as likely to demonstrate poorer quality of motor performance than the non-exposed ones $^{13}$.

Prenatal exposure to cocaine and crack has been associated with a broad spectrum of structural abnormalities in the infant brain. A retrospective study of children who were pregnant with crack and cocaine during the first days of life showed abnormalities in $34.9 \%$ of the study population ${ }^{14}$. The changes detected were subependymal cysts in 24 children (18.6\%), lentricular vascular disease in 18 children (14\%), subependymal haemorrhage in 9 children (7\%) and choroid plexus cysts in 9 children $(7 \%)^{13}$. Dixon and Bejar ${ }^{15}$, in a study of full-term new-borns exposed to cocaine and methamphetamine and evaluated by cranial ultrasonography, also identified lesions such as intraventricular haemorrhage, necrosis and cavitary lesions in the basal ganglia, frontal lobes, and posterior fossa. We emphasize that focused behavioural tests and psychophysiological measures can help to identify specific areas affected by prenatal exposure to drugs, which is essential to aid intervention measures ${ }^{16,17}$.

When analysing the index of street drugs, a greater number of licit drugs were observed (Table 1). As well as the survey carried out in the city of Maringá, Paraná, Brazil, in 2012, with 394 pregnant women assisted in basic health units, which identified the highest rate of use of licit drugs in this region, being $6.09 \%$ for alcohol use, $9,14 \%$ for cigarettes and $1.02 \%$ for street drugs ${ }^{18}$.

All pregnant women in this study who used street drugs during pregnancy used concomitant licit drugs. Licit drugs, such as alcohol or nicotine, may be equally or more detrimental to the developing fetus than illicit drugs19. In addition, most pregnant women who use illegal substances during pregnancy also use legal drugs. The multicentre study of 10,000 pregnant women conducted by Bauer et al..$^{20}$ found that $93 \%$ of all women who used cocaine or opiates during pregnancy also used alcohol and tobacco.

Exposure of the pregnant woman to alcohol and cigarette smoking has deleterious effects on fetal development in the pre and postnatal period. These include increased stillbirth rates, dysfunction of the nervous system, abortion cases, congenital abnomalies ${ }^{21}$, fetal alcohol syndrome, and developmental delay ${ }^{22}$, fetal growth disorders, low birth weight, and sudden death syndrome ${ }^{23}$.

\section{CONCLUSION}

Thus, it was concluded that infants born to mothers who used drugs of abuse had a greater delay in neuropsychomotor development.
The use of drugs of abuse is an important public health problem that requires epidemiological studies in Brazil and it is not easy to observe the occurrence of this outcome in pregnant women who are in prenatal care due to low adherence to care ${ }^{24}$. In this study, it was possible to observe a lower adherence to the prenatal consultations of mothers using abusive drugs when compared to the group of non-users, perhaps because of this also the highest number of vaginal deliveries. Corroborating this result, Oliveira et al. ${ }^{25}$, when analysing 166 women ( 83 users and 83 non-users), found that half of the group of users also did not have any prenatal visits.

In general, street drugs act on the maternal cardiovascular system, causing adrenergic hyperstimulation and vasoconstriction. There is an increase in heart rate and maternal blood pressure with consequent decrease in blood flow to the uterus and risk of restriction of fetal growth ${ }^{26}$. However, in the findings of this study, a higher prevalence of arterial hypertension was observed in nonuser mothers. High blood pressure in pregnancy is associated with unfavourable perinatal outcomes ${ }^{27}$.

According to Carvalho et al. ${ }^{28}$, arterial hypertension presents a significantly increased risk for preterm birth, intrauterine growth restriction, and NICU admission. Since the population of the present study was composed of preterm newborns, all had characteristics similar to those described above.

The newborns of both groups (Group 1 - children of street drugs users and Group 2 - children of non-users) had similar clinical conditions at birth. However, among the variables related to the neonatal complications observed in the current study, we highlight bronchopulmonary dysplasia, infection and length of stay in the NICU, with a statistically significant difference between groups. We note, however, that the possible clinical complications during the neuropsychomotor development presented by children exposed in the intrauterine life to drugs, licit or illicit, is dependent on the type of drug, the time of exposure and the amount used ${ }^{29}$.

It was also observed that neonatal infection was more prevalent in the children of mothers using drugs of abuse. Similar results were identified in studies involving infants diagnosed with neonatal sepsis. According to the authors, neonatal sepsis is a risk factor for motor development ${ }^{30,31}$, but not necessarily for cognitive ${ }^{30}$.

In addition to the use of licit and/or street drugs, other variables presented a higherrisk for delayed neuropsychomotor development, such as the length of hospital stay and the use of oxygen therapy, and especially the patent ductus arteriosus. It is known that clinical conditions at birth and hospitalization, social, psychosocial and behavioral risks may also interfere in the development of these infants ${ }^{32}$.

It is necessary to emphasize some limitations of this study as the non-evaluation of the gestational period in which the drug in question was used, since this period could also affect neuropsychomotor development. 


\section{REFERENCES}

1. Albrecht J, Lindsay B, Terplan M. Effect of waiting time on substance abuse treatment completion in pregnant women. J Subst Abuse Treat. 2011;41(1):71-7. DOI: http:/dx.doi.org/10.1016/j.jsat.2011.01.015

2. Gabrhelík R, Nechanská B, Mravcik V, Skurtveit S, Lund IO, Handal M. A unique opportunity to study short and long term consequences in children prenatally exposed to Illicit drugs and opioid maintenance treatment using czech and scandinavian registers. Cent Eur J Public Health. 2016;24(3):248-51. DOI: http:/dx.doi.org/10.21101/cejph.a4474

3. Department of Health and Human Services. Results from the 2010 national survey on drug use and health: summary of National Findings. Rockville, MD: Substance Abuse and Mental Health Services Administration; 2011.

4. Rocha PC, Alves MTSSB, Chagas DC, Silva AAM, Batista RFL, Silva RA. Prevalência e fatores associados ao uso de drogas ilícitas em gestantes da corte BRISA. Cad Saúde Pública. 2016;32(1):1-13. DOI: http://dx.doi.org/10.1590/0102-311X00192714

5. Yamaguchi ET, Cardoso MMSC, Torres MLA, Andrade AG. Drogas de abuso e gravidez. Rev Psiquiatr Clín. 2008;35(Suppl 1):44-7. DOI: http://dx.doi.org/10.1590/S0101-60832008000700010

6. Nicolau CM. Filhos de mães drogaditas. PROFISIO Programa de Atualização em Fisioterapia Pediátrica e Neonatal: Cardiorrespiratória e Terapia Intensiva.V.4. Porto Alegre: Artmed Panamericana, 2016; p.9:26.

7. Bell SG. Drug screening in neonates. Neonatal Netw. 2016;35(5):321-6. DOI: http://dx.doi.org/10.1891/0730-0832.35.5.321

8. Frankenburg WK, Dodds J, Archer P, Shapiro M, Bresnick B. The Denver II: a major revision and restandartization of the Denver developmental screening test. Pediatrics. 1992;89(1):91-7.

9. Souza SC, Leone C, Takano OA, Moratelli HB. Desenvolvimento de pré-escolares na educação infantil em Cuiabá, Mato Grosso, Brasil. Cad Saúde Pública. 2008;24(8):1917-26. DOI: http://dx.doi.org/10.1590/S0102-311X2008000800020

10. Rodrigues OMPR, Bolsoni-Silva AT. Effects of the Prematurity on the Development of Lactentes. Rev Bras Crescimento Desenvolv Hum. 2011;21(1):111-21. DOI: http://dx.doi.org/10.7322/jhgd.20000

11. Miller-Loncar C, Lester BM, Seifer R, Lagasse LL, Bauer CR, Shankaran S, et al. Predictors of motor development in children prenatally exposed to cocaine. Neurotoxicol Teratol. 2005;27(2):213-20. DOI: http://dx.doi.org/10.1016/j.ntt.2004.10.007

12. Belcher HM, Shapiro BK, Leppert M, Butz AM, Sellers S, Arch E, et al. Sequential neuromotor examination in children with intrauterine cocaine/polydrug exposure. Dev Med Child Neurol. 1999;41(4):240-6. DOI: http://dx.doi.org/10.1111/j.1469-8749.1999.tb00591.x

13. Singer LT, Moore DG, Min MO, Goodwin J, Turner JJ, Fulton S, et al. Motor delays in MDMA ( ecstasy) exposed infants persist to 2 years. Neurotoxicol Teratol. 2016;54:22-8. DOI: http://dx.doi.org/10.1016/j.ntt.2016.01.003

14. Lucca J, Baldisserotto M. Cerebral ultrasound findings in infants exposed to crack cocaine during gestation. Pediatr Radiol. 2013;43(2):212-8. DOI: http://dx.doi.org/10.1007/s00247-012-2528-6

15. Dixon SD, Bejar R. Echoencephalographic findings in neonates associated with maternal cocaine and methamphetamineuse: incidence and clinical correlates. J Pediatr. 1989;115(5 Pt 1):770-8.

16. Konijnenberg $\mathrm{C}$. Methodological issues in assessing the impact of prenatal drug exposure. Subst Abuse. 2015;9(Suppl.2):39-44. DOI: http://dx.doi.org/10.4137/SART.S23544

17. Sampaio TF, Nogueira KPA, Pontes TB, Toledo AM. Comportamento motor de lactentes prematuros de baixo peso e muito baixo peso ao nascer. Fisioter Pesq. 2015;22(3):253-60. DOI: http://dx.doi.org/10.590/1809-2950/13533022032015

18. Kassada DS, Marcon SS, Pagliarini MA, Rossi RM. Prevalência do uso de drogas de abuso por gestantes. Acta Paul Enferm. 2013;26(5):467-71. DOI: http://dx.doi.org/10.1590/S0103-21002013000500010

19. Slotkin TA. Fetal nicotine or cocaine exposure: which one is worse? J Pharmacol Exp Ther. 1998;285(3):931-45.

20. Bauer CR, Shankaran S, Bada HS, Lester B, Wright LL, Krause-Steinrauf H, et al. The maternal lifestyle study: drug exposure during pregnancy and short-term maternal outcomes. Am J Obstet Gynecol. 2002;186(3):487-95. DOI: https://doi.org/10.1067/mob.2002.121073

21. Momimo W, Sanseverino MTV, Schüler-Faccin L. A exposição pré-natal ao álcool como fator de risco para comportamentos disfuncionais: o papel do pediatra. J Pediatr. 2008;84(Suppl 4):76-9. DOI: http://dx.doi.org/10.1590/S0021-75572008000500011

22. Ornoy A, Ergaz Z. Alcohol abuse in pregnant women: effects on the fetus and newborn, mode of action and maternal treatment. Int J Environ Res Public Health. 2010;7(2):364-79. DOI: http://dx.doi.org/10.3390/ijerph7020364

23. Marin GH, Delgado L, Sager G, Visentín S, Azzaro S, Tozzi M. Consequences of smoking during pregnancy for mother and child. Saúde Mater Infant. 2003;3(2):159-64. DOI: http://dx.doi.org/10.1590/S1519-38292003000200005

24. Lendoiro E, González-Colmenero E, Concheiro-Guisán A, Castro A, Cruz A, López-Rivadulla M, et al. Maternal hair analysis for the detection of Illicit drugs, medicines, and alcohol exposure during pregnancy. Ther Drug Monit. 2013;35(3):296-304. DOI: http://dx.doi.org/10.1097/FTD.0b013e318288453f

25. Oliveira TA, Bersusa AAS, Santos TF, Aquino MMAA, Mariani Neto C. Perinatal outcomes in pregnant women users of Illegal drugs. Rev Bras Ginecol Obstet. 2016;38(4):183-8. DOI: http://dx.doi.org/10.1055/s-0036-1580710 
26. White SM, Lambe CJ. The pathophysiology of cocaine abuse. J Clin Forensic Med. 2003;10(1):27-39. DOI: http://dx.doi.org/10.1016/S1353-1131(03)00003-8

27. Vettore MV, Dias M, Domingues RMSM, Vettore MV, Leal MC. Cuidados pré-natais e avaliação de manejo da hipertensão arterial em gestantes do SUS no município do Rio de Janeiro, Brasil. Cad Saude Publica. 2011;27(5):1021-34. DOI: http://dx.doi.org/10.1590/S0102-311X2011000500019

28. Carvalho MAB, Melo VH, Zimmermmann JB. Resultados perinatais de gestantes com síndrome hipertensiva da Santa Casa de Misericórdia de Barbacena, Minas Gerais: estudo controlado. Rev Med Minas Gerais. 2008;18(4):260-6.

29. Melo VH, Botelho AOM, Maia MMM, Júnior MDC, Pinto JA. Uso de drogas ilícitas por gestantes infectadas pelo HIV. Rev Bras Ginecol Obstet. 2014;36(12):555-61. DOI: http://dx.doi.org/10.1590/So100-720320140005155

30. Castellanos GRR, Rodríguez SLR. Neonatal sepsis and neurodevelopment in very low birth weight infants in Matanzas, Cuba 2006- 2010: a prospective cohort study. Medwave. 2016;16(3):e6422. DOI: http://dx.doi.org/10.5867/medwave.2016.03.6422

31. Ferreira RC, Mello RR, Silva KS. Neonatal sepsis as a risk factor for neurodevelopmental changes in preterm infants with very low birth weight. J Pediatr. 2014;90(3):293-9. DOI: http://dx.doi.org/10.1016/j.jped.2013.09.006

32. Schempf AH. Ilicit drug use and neonatal outcomes: a critical review. Obstet Gynecol Surv. 2007;62(11):749-57. DOI: http://dx.doi.org/10.1097/01.ogx.0000286562.31774.76

\section{Resumo}

Introdução: O uso de drogas de abuso durante a gestação, em decorrência dos seus efeitos deletérios à saúde do lactante, pode acarretar implicações clínicas para o desenvolvimento neuropsicomotor.

Objetivo: Analisar as características do desenvolvimento neuropsicomotor de lactentes filhos de mães usuárias de drogas de abuso na gestação.

Método: Estudo retrospectivo transversal, que analisou 51 prontuários de lactentes nascidos com peso inferior a 1500 gramas, no Hospital de Clínicas da Universidade Federal de Uberlândia (HC/UFU), entre janeiro de 2014 a dezembro de 2015. A avaliação do desenvolvimento neuropsicomotor foi realizada por meio do teste de Triagem do Desenvolvimento Denver II aos 6 ou 9 meses de idade corrigida. A análise estatística incluiu variáveis quantitativas que foram descritas por meio de médias, medianas e desvios-padrão e grupos comparados pelo teste t ou Mann-Whitney. As associações das variáveis qualitativas foram avaliadas por meio do teste de razão de verossimilhança.

Resultados: Dos 51 prontuários analisados, 39,2\% pertenciam ao grupo de filhos de mães usuárias de drogas de abuso e $60,8 \%$ ao grupo de filhos de mães não usuárias. O desenvolvimento neuropsicomotor foi predominantemente anormal e com diferença significante na classificação geral de desempenho $(p<0,001)$ e, especificamente, na área motor grosseira $(p=0,003)$ do grupo de lactentes filhos de mães usuárias de drogas de abuso.

Conclusão: Lactentes filhos de mães usuárias de drogas de abuso apresentaram maior atraso no desenvolvimento neuropsicomotor

Palavras-chave: drogas llícitas, lactentes, desenvolvimento infantil, gestantes.

๑ The authors (2018), this article is distributed under the terms of the Creative Commons Attribution 4.0 International License (http://creativecommons.org/licenses/by/4.0/), which permits unrestricted use, distribution, and reproduction in any medium, provided you give appropriate credit to the original author(s) and the source, provide a link to the Creative Commons license, and indicate if changes were made. The Creative Commons Public Domain Dedication waiver (http://creativecommons.org/publicdomain/ zero/1.0/) applies to the data made available in this article, unless otherwise stated. 